\title{
Multistage resection of esophageal squamous cell cancer of the cardia - successful despite complications
}

\author{
Jacek Zieliński ${ }^{1}$, Anna Ptach ${ }^{2}$, Andrzej Sadowski ${ }^{3}$, Iwona Chruścicka ${ }^{1}$, Rafał Pęksa ${ }^{4}$, Piotr Rak ${ }^{1}$ \\ ${ }^{1}$ Department of Surgical Oncology, Medical University of Gdańsk, Poland \\ ${ }^{2}$ Hospital Emergency Ward, St. Vincent a Paulo Hospital in Gdynia, Poland \\ ${ }^{3}$ Department of General Surgery, Tczew Hospitals JSC, Poland \\ ${ }^{4}$ Department of Pathology, Medical University of Gdańsk, Poland
}

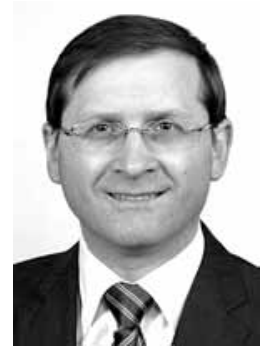

Kardiochirurgia i Torakochirurgia Polska 2015; 12 (3): 255-258

\begin{abstract}
Surgery is the treatment of choice for squamous cell esophageal cancer. Complete resection of the esophagus with reconstruction of the digestive tract is performed for tumors located in the chest or cardia. The aim of the report is to present the case of a complete esophageal and gastric resection complicated by colon graft necrosis. The patient was a 45-year-old woman diagnosed with cancer of the cardia infiltrating the distal section of the esophagus and the body and fundus of the stomach. The initial surgical procedure included the opening of three body cavities followed by resection of the thoracic esophagus, stomach, and a portion of the left hepatic lobe. Right colon interposition was performed to restore digestive tract continuity. On the 8th day, a leak was observed in the esophagointestinal anastomosis. Management consisted in two surgical procedures, one of which ended in the removal of the colon patch. The fourth and final procedure was conducted after 10 months.
\end{abstract}

Key words: esophageal cancer, esophageal resection, complications.

\section{Introduction}

The treatment of choice for esophageal squamous cell carcinoma (ESCC) is surgery. However, only $40 \%$ of patients are eligible for radical surgical procedures (Tis-T3 NO-1 MO) $[1,2]$. The methods of surgical treatment for ESCC in the thoracic region and the cardia include radical esophagectomy with subsequent reconstruction of the gastrointestinal tract using fragments of the stomach, colon, or (significantly less often) the small intestine $[3,4]$. The success of the procedure depends on many factors; the most important include the grafting technique and the type of anastomosis $[5,6]$. The place of anastomosis between the esophageal stump and the organ used to reconstruct the digestive

\section{Streszczenie}

Podstawową metodą leczenia raka płaskonabłonkowego przełyku w odcinku piersiowym jest zabieg chirurgiczny. Wśród metod chirurgicznych leczenia tego raka przy lokalizacji w klatce piersiowej oraz we wpuście jest operacja radykalna usunięcia przełyku. Celem pracy jest przedstawienie chorej po resekcji radykalnej przełyku i żołądka, powikłanej martwicą wstawki z jelita grubego. U 45-letniej chorej rozpoznano raka wpustu z naciekiem dystalnej części przełyku oraz dna i trzonu żołądka. Pierwotny zabieg operacyjny wykonano z otwarciem trzech jam ciała, w czasie którego resekowano piersiowy odcinek przełyku, żołądek i fragment lewego płata wątroby. Ciągłość przewodu pokarmowego odtworzono za pomocą uszypułowanej prawej połowy jelita grubego. W 8. dobie pooperacyjnej rozpoznano nieszczelność zespolenia przełykowo-jelitowego. Przeprowadzono dwie kolejne operacje, z których jedna została zakończona usunięciem wstawki z jelita grubego. Czwarty i ostateczny zabieg przeprowadzono po 10 miesiącach.

Słowa kluczowe: rak przełyku, resekcja przełyku, powikłania.

tract may be affected by complications such as leaks or stenoses. Anastomotic leak is an early complication observed between the $6^{\text {th }}$ and $9^{\text {th }}$ postoperative day, whereas stenosis is a late complication occurring 4-6 weeks after surgery [7]. The aim of this paper is to present the case of a patient who underwent radical resection of the esophagus and stomach, complicated by necrosis of the colonic graft. After several procedures, the treatment was successful.

\section{Case study}

The 45-year-old patient was admitted to the clinic due to esophageal cancer resulting in grade 3 dysphagia (swallow-

Address for correspondence: Ass. Prof. Jacek Zieliński, Department of Surgical Oncology, Medical University of Gdańsk, 17 Smoluchowskiego St., 80-214 Gdańsk, Poland, phone: +48 5834931 90, e-mail: jaziel@gumed.edu.pl 

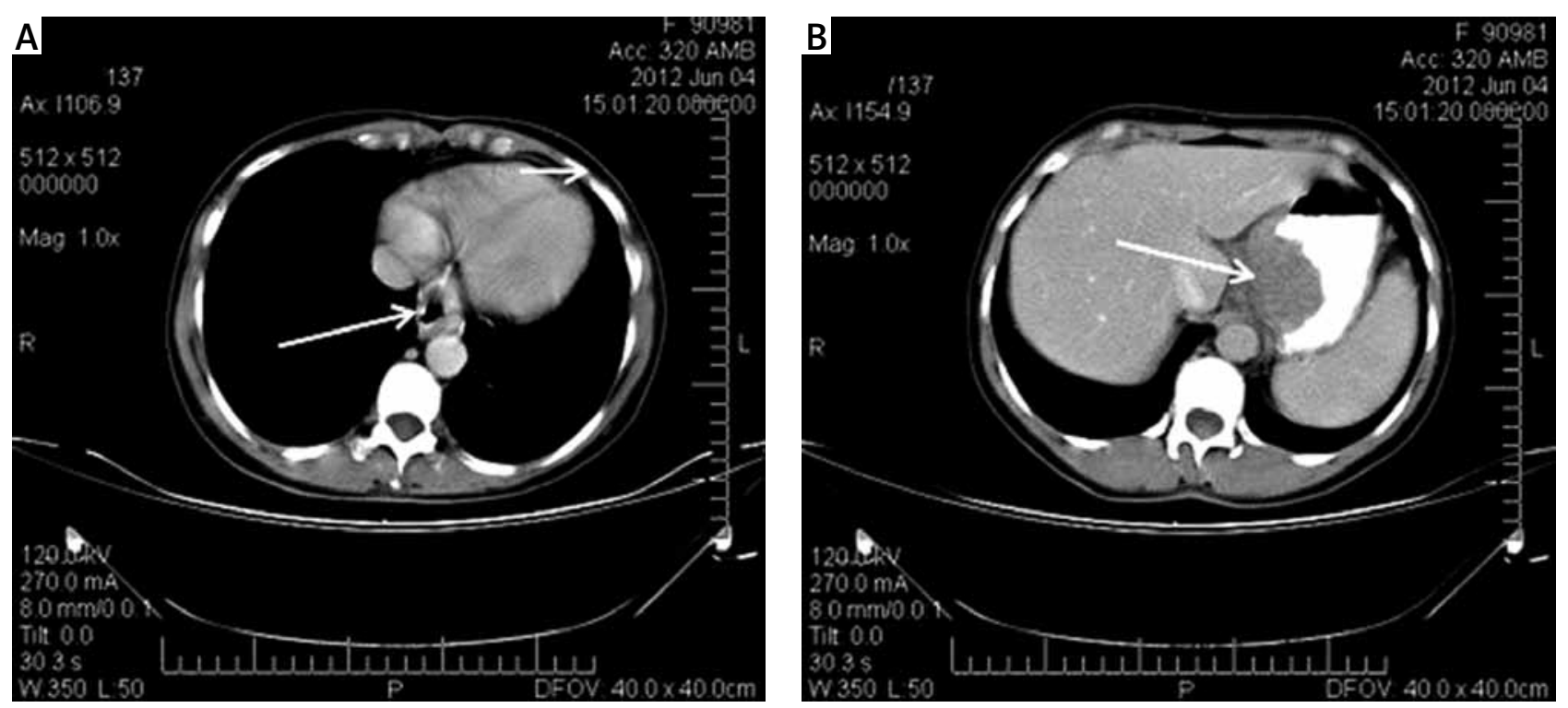

Fig. 1. Preoperative computed tomography. A) At the level of the cardia, B) at the level of the gastric fundus (the arrows indicate the location of the tumor)

ing liquids only) and malnutrition (Nutritional Risk Score: 5). Radiological examination with oral contrast revealed a stenosis in the vicinity of the cardia and an irregular contour of the gastric fundus. Gastroscopy demonstrated the presence of a neoplastic infiltrate starting $35 \mathrm{~cm}$ from the dental margin and extending into the gastric fundus. Histopathological examination of the samples obtained during gastroscopy yielded the diagnosis of squamous cell carcinoma. Computed tomography revealed a thickening of the distal part of the esophagus (Fig. 1A) and the gastric fundus (Fig. 1B) up to $5 \mathrm{~cm}$, without signs of pathology

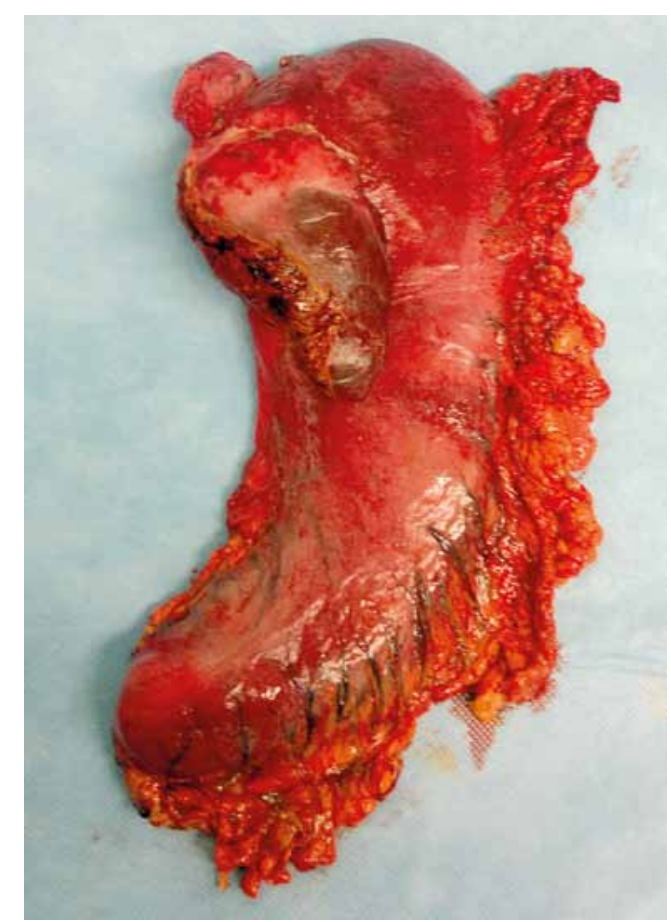

Fig. 2. Macroscopic image of the removed stomach with the tumor of the cardia and part of the left hepatic lobe in the perigastric or mediastinal lymph nodes (UICC TNM: T2NOMO). The patient was qualified for a surgical procedure consisting in esophageal resection using the Akiyama method. During the 10 days before the procedure, only parenteral feeding was employed.

\section{Surgical procedures}

The first procedure was performed under general anesthesia. The patient was lying in a supine position, and access to the left side of her neck was ensured. After opening the abdominal cavity, infiltration of the gastric fundus was revealed along with a massive adhesion with the left lobe of the liver, but the disease had not disseminated across the abdominal cavity. As the neoplasm involved a significant portion of the stomach, the operative strategy was changed to complete gastrectomy with partial resection of the left hepatic lobe and the thoracic segment of the esophagus. Restoration of gastrointestinal continuity using the large intestine was planned. The abdominal stage of the procedure consisted in total gastrectomy with D2 lymphadenectomy with resection of segments 2 and 3 of the liver. Firstly, the greater curvature was freed, sparing the spleen. Skeletonization from the side of the lesser curvature was preceded by resection of hepatic segments 2 and 3. Next, after the ligation of the left gastric vessels, the whole stomach was removed along with the regional lymph nodes (Fig. 2). The distal part of the stomach was excised, and the stump of the duodenum was closed with a linear stapler; in turn, the proximal side of the stomach was excised in the area above the cardia after the diaphragmatic crura were transected. The right half of the colon was used to restore the continuity of the gastrointestinal tract between the esophagus and the isolated loop of the jejunum using the Roux-Y method. The continuity of the large intestine was restored by ileotransversostomy. In order to anastomose the colonic graft with the cervical esophagus, an incision was made along the 
left sternocleidomastoid muscle. As the evaluation of heart rate in the distal part of the graft was impeded, intraoperative Doppler examination was performed, revealing a disturbance in the blood supply to the ultimate fragment of the large intestine; subsequently, a resection of the ischemic part of the large intestine was performed. After the cervical esophagus was excised from the thoracic part of the esophagus, anastomosis was performed with the previously prepared colonic graft, which was interposed through a tunnel created in the frontal mediastinum. The anastomosis between the esophageal stump and the large intestine was performed end-to-side using a circular stapler (EEA 21, Tyco, USA). The distal end of the colonic graft was anastomosed with the isolated Roux-Y loop. Additionally, a feeding fistula was created on the next loop of the jejunum. The remaining portion of the esophagus was removed by opening the right half of the chest. The first 7 postoperative days were uneventful. On the $8^{\text {th }}$ day after the procedure, signs of wound infection and increasing subcutaneous emphysema were found on the patient's neck. Radiological examination using oral contrast confirmed the presence of a leak in the frontal part of the anastomosis. Postoperative histopathological examination confirmed the diagnosis of esophageal squamous cell carcinoma (UICC PTNM: T2NOMO). The performed surgery was radical.

The second procedure was performed on the $13^{\text {th }}$ postoperative day. During the surgery, a decision was made to revise the anastomosis between the esophagus and the large intestine. The location of the leak was sutured and the lines of anastomosis were covered with collagen tissue glue.

However, on the $16^{\text {th }}$ postoperative day, the patient's general condition deteriorated; she was diagnosed with sepsis with signs of systemic inflammatory response syndrome and increasing infection of the neck wound. These signs were absolute indications for another surgical intervention.

The third surgical procedure consisted in revising the neck wound and reopening the abdominal cavity to remove the colonic graft. The stump of the Roux-Y loop was closed, and a salivary fistula was created out of the esophageal stump. After this procedure, the patient's general condition gradually improved. On the $23^{\text {rd }}$ postoperative day, the pa-

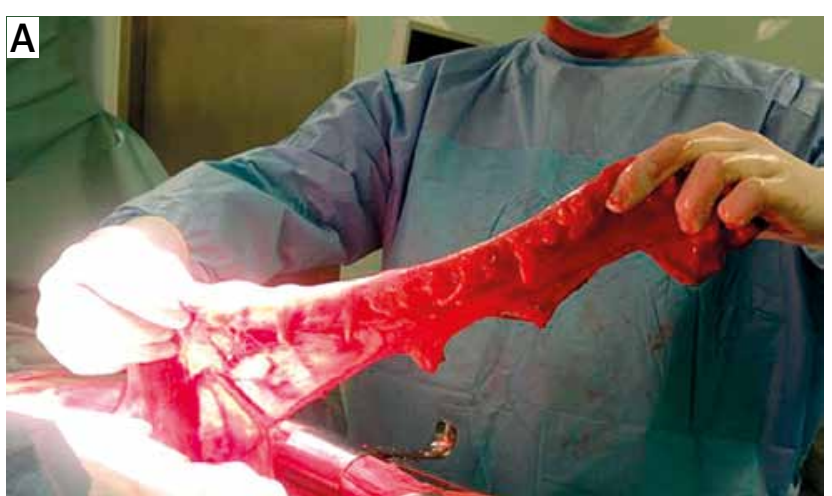

Fig. 3. Intraoperative image (taken immediately before the performance of anastomosis) of the isolated graft created from the left side of the colon. A) Graft with visible vessels. B) Evaluation of the graft's length to the cervical anastomosis

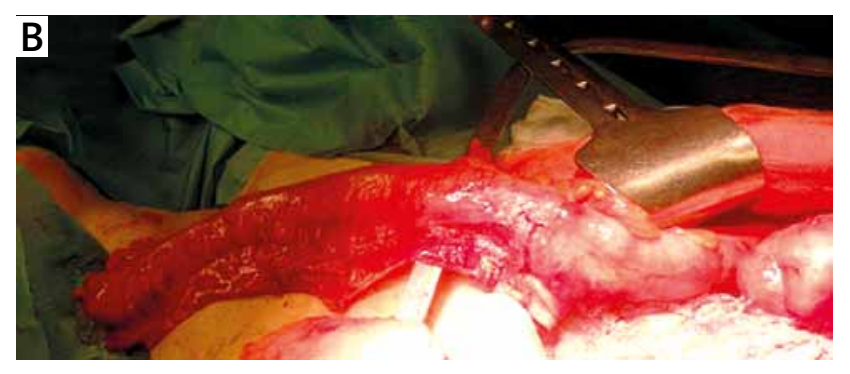

tient was discharged home with the recommendation of enteral feeding using a feeding microfistula. Histopathological examination of the colonic graft showed signs of ischemia within the mucous membrane.

The fourth procedure was performed 10 months after the initial surgery; its purpose was the reconstruction of the part of the preparations for the surgery, a PET scan was performed, revealing no signs of locoregional recurrence or neoplastic diffusion. During the surgery, an isolated graft was created out of the left side of the colon; its proximal end was anastomosed with the esophageal stump, while the distal end was anastomosed with the Roux-Y loop (Fig. 3). The postoperative course was uneventful, and the patient was discharged on the $8^{\text {th }}$ postoperative day. Further follow-up examinations were conducted on an out-patient basis. The time of follow-up since the last procedure is 3 months; during this time, the patient's body weight has increased, her nutrition has improved, and no early or late complications have been observed.

\section{Discussion}

The proper selection of the extent of surgery in the case of cancer of the cardia is challenging for surgical teams due to the tumor's location on the margin between the abdominal cavity and the chest. In the present case, the extent of tumor removal was based on the preoperative histopathological diagnosis. The patient was diagnosed with squamous carcinoma, which is less common in this location in comparison with adenocarcinoma. According to literature data, these two types of neoplasms require different operative strategies in order to achieve a radical resection. In the case of adenocarcinoma of the cardia, this requires gastrectomy with resection of the distal part of the esophagus and thoracic anastomosis [8]. In view of the diagnosis of squamous carcinoma of the cardia, a decision was made to perform additional resection of the thoracic segment of the esophagus with cervical anastomosis due to the increased risk of skip metastases associated with this type of tumor and in order to perform two-field lymphadenectomy [1]. A possible alternative to the Akiyama procedure would digestive tract using the remaining left side of the colon. As 
have been to perform gastrectomy and partial esophageal resection with thoracic anastomosis, but the surgical team was concerned that this procedure would not have been radical enough and that it would be impossible to monitor the performed anastomosis.

Restoring the continuity of the gastrointestinal tract after esophageal resection is most commonly performed using stomach tissue; less commonly, the colon is employed for this purpose. The anastomosis is most often created in the neck, which allows for better clinical supervision of the anastomosis location; it is also associated with less severe side effects if a leak develops [3, 4]. In the present patient, the anastomosis was cervical, which enabled the surgical team to open the wound early and apply drainage. Notwithstanding, the method proved to be insufficient, forcing the surgeon to remove the whole colonic graft.

Another significant factor influencing the quality of an anastomosis is the technique of its performance. At present, both manual and mechanical anastomoses are performed $[5,6]$. There is currently no uniform optimal standard concerning the method of performing cervical esophagogastric anastomosis. In the present case, stapler anastomosis was performed during the first procedure, and manual one-layer anastomosis was used during the repair procedure.

Most authors agree that surgical treatment of esophageal cancer should be performed in centers that employ surgeons with excellent operative technique and sufficient experience with regard to the proper selection of patients for the procedure $[1,9]$. The authors of this report work at a clinic which has over 40 years of experience with treating esophageal cancer [8]. In the present case, preoperative endoscopy and computed tomography indicated that it was feasible to perform esophageal resection using the Akiyama method. However, the greater extent of the neoplastic infiltrate within the stomach and the presence of a massive adhesion with the left lobe of the liver resulted in a change of operative strategy. This report confirms that individualization of surgical management is a crucial factor in oncological surgery [10]. The experience accumulated in our clinic by several generations of surgeons enabled us to reduce postoperative mortality to $7.8 \%$ and achieve $18 \%$ 5-year survival among esophageal cancer patients treated with radical surgery [1].

\section{Disclosure}

Authors report no conflict of interest.

\section{References}

1. Zieliński J, Świerblewski M, Kruszewski WJ, Jaworski R, Haponiuk I, Irga N, Kopacz A, Jaśkiewicz J. Doświadczenia jednego ośrodka klinicznego w chirurgicznym leczeniu raka płaskonabłonkowego przełyku w latach 1970-2007. Kardiochir Torakochir Pol 2011; 8: 71-76.

2. Zieliński J, Kruszewski WJ, Jaworski R, Haponiuk I, Irga N, Zygoń J, Kopacz A, Jaśkiewicz J. Rare oesophageal tumours: experience of one centre. Eur Surg 2012; 44: 361-365.

3. Orringer MB, Marshall B, lannettoni MD. Eliminating the cervical esophagogastric anastomotic leak with a side-to-side stapled anastomosis. J Thoracic Cardiovascular Surg 2000; 119: 277-287.

4. Nederlof N, Tilanus HW, Tran TCK, Hop WCJ, Wijnhoven BPL, de Jonge J. Endto-End Versus End-to-Side Esophagogastrostomy After Esophageal Cancer Resection A Prospective Randomized Study. Ann Surg 2011; 254: 226-233.

5. Xu QR, Wang KN, Wang WP, Zhang K, Chen LQ. Linear stapled esophagogastrostomy is more effective than hand-sewn or circular stapler in prevention of anastomotic stricture: a comparative clinical study. J Gastrointestinal Surg 2011; 15: 915-921.

6. Hsu HH, Chen JS, Huang PM, Lee JM, Lee YC. Comparison of manual and mechanical cervical esophagogastric anastomosis after esophageal resection for squamous cell carcinoma: a prospective randomized controlled trial. Eur J Cardiothoracic Surg 2004; 25: 1097-1101.

7. Kruszewski WJ. The methods of anastomosing the esophagus to other organs - a review of literature. Nowotwory J Oncology 2009; 59: 99-103.

8. Jaworski R, Bollschweiler E, Holscher AH, Monig SP, Skokowski J, Zieliński J, Świerblewski M, Kopacz A, Jaśkiewicz J. Prognostic relevance of demographics and surgical practice for patients with gastric cancer in two centers: in Poland versus Germany. Gastric Cancer 2011; 14: 234-241.

9. Jaworski R, Haponiuk I, Chojnicki M, Irga N, Wiśniewska B, Treder E, Ziółkowska I, Steffens M, Zieliński J. Programme to improve hygene in a paediatric cardiac surgery. Kardiochir Torakochir Pol 2012; 2: 278-282.

10. Zieliński J, Jaworski R, Pawlaczyk R, Świerblewski M, Kabata P, Jaśkiewicz J, Rogowski J. Simultaneous surgery for critical aortic stenosis and gastric cancer: a case report. World J Gastroenterol 2010; 16: 1161-1164. 